\title{
WORKSHOP ONLINE PEMBUATAN KAPAL KECIL UNTUK NELAYAN DI KABUPATEN SITUBONDO
}

\section{ONLINE WORKSHOP OF THE MAKING OF SMALL VESSEL FOR FISHERMAN IN SITUBONDO DISTRICT}

\author{
Ruddianto ${ }^{\text {1) }}$, Agung Prasetyo Utomo ${ }^{2)}$, Sumardiono ${ }^{3)}$, Kharis Abdullah ${ }^{4)}$, Kiki \\ Dwi Wulandari ${ }^{5)}$ \\ 1,2,3,4,5 Teknik Perancangan dan Konstruksi Kapal, Politeknik Perkapalan Negeri Surabaya \\ ${ }^{1}$ Email: ruddianto@ppns.ac.id
}

\begin{abstract}
Abstrak: Nelayan Indonesia yang terdata pada Satu Data Kementerian Kelautan dan Perikanan (KKP) per 23 Maret 2020 berjumlah 1.459 .874 orang. Pada data yang dirilis oleh Ditjen Perikanan Tangkap jumlah kapal di bawah 5 GT sebanyak 115.814 unit, kapal 5-10 GT sebanyak 35.988 unit, kapal 10-20 GT sebanyak 9.790 unit. Berikutnya kapal 20-30 GT sebanyak 6.481 unit, kapal 30-50 GT sebanyak 805 unit, kapal 50-100 GT sebanyak 2.008 unit, kapal 100-200 GT sebanyak 847 unit dan di atas 200 GT ada 11 unit. Dengan data yang ada, bisa dilihat bahwasanya nelayan di Indonesia masih banyak menggunakan kapal kecil sebagai sarana untuk melakukan penangkapan ikan di laut, dan dikategorikan sebagai nelayan kecil. Dalam upaya peningkatan kemandirian masyarakat nelayan untuk membuat kapal kecil berbahan fiberglass, tim pengabdian masyarakat PPNS menggandeng pihak Industri Galangan Kapal fiberglass yaitu PT. Samudra Sinar Abadi (SSA) serta Pihak Dinas Perikanan Kabupaten Situbondo, mengadakan pengabdian masayarakat berupa pelatihan bagi nelayan khususnya masyarakat nelayan Kabupaten Situbondo tentang pembuatan kapal kecil berbahan fiberglass yang dilakukan secara online dan offline. Kegiatan ini dilakukan dengan memenuhi standar protokol kesehatan penyelenggaraan kegiatan pada masa pandemi Covid-19. Kegiatan pengabdian masyarakat ini dilakukan secara daring yang dapat diakses oleh seluruh masyarakat Indonesia. Antusias dalam pelaksanaan kegiatan sangat baik. Ini dapat dilihat dari hasil kuisioner umpan balik (feed back) yang dilakukan oleh peserta secara daring (73 orang) dan luring (15 orang) mendapatkan hasil dimana rata-rata nilai indikator kesesuaian workshop di atas $86 \%$, serta usulan kegiatan lanjutan dengan praktek langsung diatas angka $78 \%$.
\end{abstract}

Kata Kunci: Kapal kecil, Nelayan, Fiberglass

Abstract: Indonesian Fishermen recorded on The Data from the Ministry of Marine Affairs and Fisheries (KKP) per March 23, 2020, amounted to 1.459.874 people. The data released by The Directorate General of Fisheries capture the number of ships in under 5 GT as much as 115.814 units, ship 5-10 GT as much as 35.988 units, ship 10-20 GT as much as 9.790 units. Next, ship 20-30 GT as much as 6.481 units, ship 30-50 GT as much as 805 units, ships of 50-100 GT as much as the 2008 units, ship 100-200 GT as much as 847 units and above 200 GT there are 11 units. With the existing data, it can be seen that the fishermen in 
Indonesia there are still many using a small vessel as a means of catching fish in the sea and is categorized as small fishing. To increase the independence of the community of fishermen to make small ships are made of fiberglass, the community service team PPNS cooperating with the Shipbuilding Industry fiberglass, namely PT. Ocean of Eternal light (SSA) and the Department of Fisheries Situbondo, held the devotion of the community in the form of training for fishermen in particular the fishing community Situbondo about the making of the small ships are made of fiberglass that is done online and offline. This activity is conducted in compliance with the standard protocol of the health of the implementation of the activities on the pandemic of Covid-19. This community service activity is performed online that can be accessed by all Indonesian people. Enthusiastic in the implementation of the activities, very well. This can be seen from the results of the questionnaire feedback (feedback) performed by participants online (73 people) and offline (15 people) to get results where the average value of the indicator of the suitability of the workshop above $86 \%$, and the proposed activities continued with the practice directly above the figure of $78 \%$.

Keywords: Small vessels, Fishermen, Fiberglass

\section{PENDAHULUAN}

Kehidupan maritim Indonesia saat ini ditopang oleh sektor perikanan tangkap, dimana perikanan hasil tangkapan laut memiliki porsi yang besar. Perikanan tangkap di laut tidak terlepas dari nelayan yang hampir setiap hari melakukan aktivitas penangkapan ikan. Perikanan tangkap yang dilakukan terbatas pada daerah sekitar pantai dan landasan kontinen. Penangkapan ikan di laut membutuhkan berbagai peralatan yang memadai dikarenakan faktor alam di laut yang cukup ekstrim dan cepat berubah. Jumlah nelayan Indonesia yang terdata pada Satu Data Kementerian Kelautan dan Perikanan (KKP) per 23 Maret 2020 berjumlah 1.459 .874 orang. Menilik pada data Ditjen Perikanan Tangkap KKP tahun 2016, jumlah perahu atau kapal perikanan laut di Indonesia tercatat sebanyak 54.845 unit. Dengan rasio antara jumlah nelayan dan jumlah kapal yang ada, maka dapat dilihat bahwa satu kapal digunakan lebih dari sepuluh orang. Pada data yang dirilis oleh Ditjen Perikanan tangkap jumlah kapal di bawah 5 GT sebanyak 115.814 unit, kapal 5-10 GT sebanyak 35.988 unit, kapal 10-20 GT sebanyak 9.790 unit. Berikutnya kapal 20-30 GT sebanyak 6.481 unit, kapal 3050 GT sebanyak 805 unit, kapal 50-100 GT sebanyak 2.008 unit, kapal 100-200 GT sebanyak 847 unit dan di atas 200 GT ada 11 unit. Dengan data yang ada, bisa 
dilihat bahwasanya nelayan di Indonesia masih banyak menggunakan kapal kecil sebagai sarana untuk melakukan penangkapan ikan di laut, dan dikategorikan sebagai nelayan kecil.

Kapal ikan 5 GT memiliki ukuran panjang kurang lebih 12 meter, dengan lebar kapal 3 meter, kapal ikan 5 GT merupakan kategori kapal kecil (small vessel) menurut aturan dari Badan Klasifikasi. Dengan ukuran kapal di bawah 5 GT maka nelayan kecil hanya bisa menjangkau perairan pesisir untuk operasional penangkapan ikan. Berbagai jenis kapal nelayan tradisional yaitu ketinting, jaten, placuk dan lain-lain, sesuai dengan penamaan di daerah masing-masing. Dapat dilihat pada Gambar 1 kapal ikan jenis ketinting yang banyak digunakan oleh nelayan Indonesia, dengan panjang 6 meter.

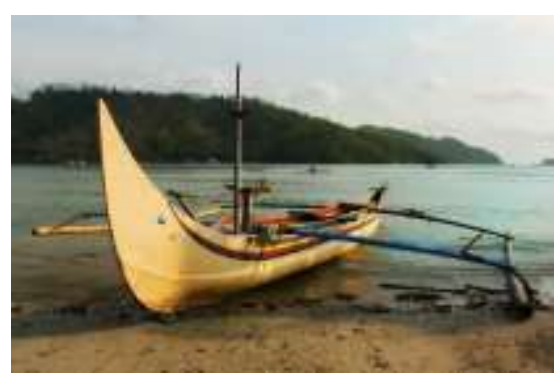

Gambar 1. Kapal ikan jenis ketinting

Kayu merupakan salah satu bahan yang banyak digunakan oleh nelayan tradisional sebagai bahan utama pembuatan kapal kecil. Bahan kayu merupakan bahan yang didapat dari pengambilan langsung di hutan maupun perkebunan rakyat. Kapal nelayan tradisional dengan menggunakan bahan kayu memiliki berat yang cukup besar dibandingkan dengan kapal berbahan aluminium atau fiberglass. Dan ketahanan yang dimiliki kapal berbahan kayu cukup rendah dibandingkan dengan kapal berbahan fiberglass. Perkembangan teknologi kapal berbahan fiberglass semakin maju, banyak penggunaan kapal berbahan fiberglass sebagai kapal ikan, kapal penumpang dan lain-lain. Pembangunan kapal dengan berbahan fiberglass relatif lebih cepat dan lebih mudah dibandingkan dengan kapal ikan berbahan kayu. Selain itu, kapal berbahan fiberglass memiliki lifetime penggunaan yang lebih lama dibandingkan dengan kapal berbahan kayu. Selain itu pembangunan kapal berbahan fiberglass lebih murah dibandingkan dengan 
kapal berbahan kayu. Seperti terlihat pada Gambar 2 kapal nelayan berbahan fiberglass.

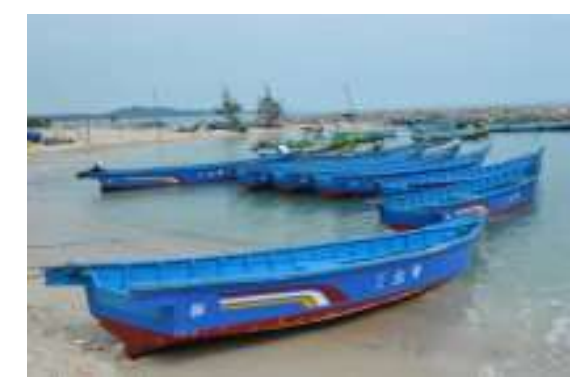

Gambar 2. Kapal nelayan berbahan fiberglass

Kemandirian nelayan dalam pembuatan kapal berbahan fiberglass sebagai salah satu bentuk mengurangi ketergantungan terhadap sumber daya kayu yang diambil dari alam serta meningkatkan taraf hidup nelayan, merupakan upaya yang dilakukan sebagai sumbangsih terhadap kemajuan bangsa dan negara. Potensi atas kemandirian dalam pembuatan kapal sangat terbuka luas, dikarenakan metode pembuatan kapal berbahan fiberglass lebih mudah dan bahan yang dibutuhkan lebih murah dibandingkan dengan menggunakan kayu.

Pada masa pandemi Covid-19 ini, berbagai kegiatan dan acara dihentikan untuk sementara waktu. Ini dilakukan sebagai upaya untuk mencegah penularan virus secara luas. Berbagai instansi pemerintahan dan instansi pendidikan memberlakukan work from home (WFH) dan pembelajaran jarak jauh (PJJ) bagi karyawan dan siswa. Protokol kesehatan yang ketat diberlakukan bagi masyarakat ketika melakukan perjalanan atau berpergian. Perguruan Tinggi sebagai salah satu instansi pendidikan, harus tetap berinovasi demi memajukan bangsa dan negara. Salah satu kewajiban perguruan tinggi yaitu melaksanakan pengabdian masyarakat, dimana pada masa pandemi Covid-19 ini, perguruan tinggi melaksanakan pengabdian dengan metode Pembelajaran Jarak Jauh (PJJ) dengan sistem dalam jaringan (daring). Pelatihan dengan sistem daring ini diharapkan dapat meningkatkan melek teknologi bagi masyarakat secara khusus bagi nelayan. Pelatihan pembuatan kapal kecil bagi nelayan yang dilakukan secara daring ini diharapkan dapat meningkatkan pengetahuan dan taraf hidup bagi nelayan atau masyarakat umum yang mengikutinya, karena potensi akan pembangunan kapal kecil berbahan fiberglasss secara mandiri sangat besar, dikarenakan banyak 
kemudahan dalam proses pembangunan kapal kecil ini, serta biaya yang murah dibandingkan dengan kapal berbahan kayu.

\section{METODE}

Pelaksanaan pengabdian masyarakat workshop online pembuatan kapal kecil ini melalui program kolaborasi Pengabdian Masyarakat Politeknik Perkapalan Negeri Surabaya dengan Dinas Perikanan Kabupaten Situbondo, serta dari pihak industri PT. Samudra Sinar Abadi. Metode pelaksanaan kegiatan yaitu :

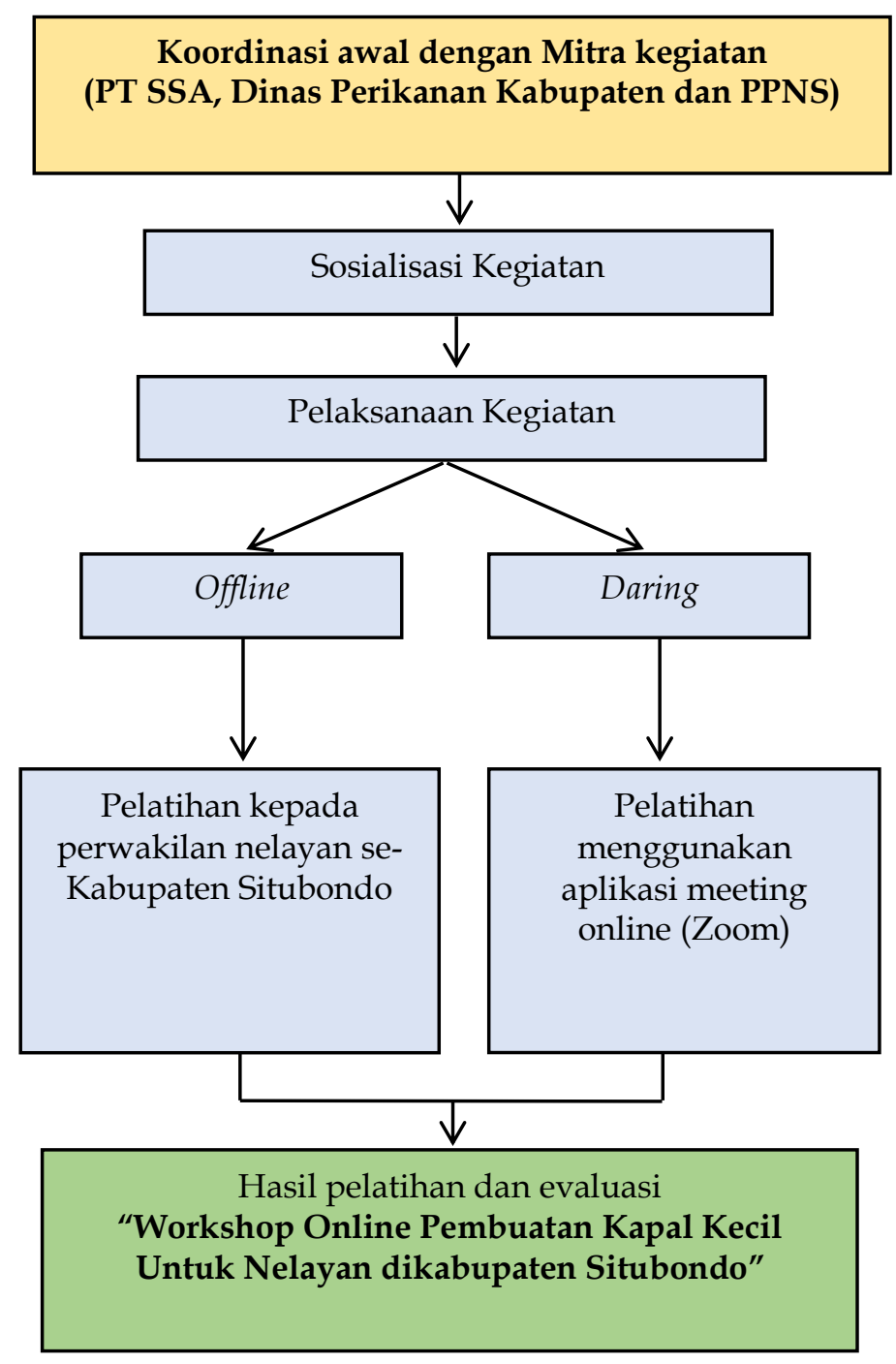

Gambar 3. Metode pelaksanaan

Gambar 3 diatas merupakan metode pelaksanaan saat kegiatan workshop online akan dilaksanakan. Kegiatan koordinasi awal dilaksanakan untuk menentukan konsep, waktu, hingga pelaksanaan kegiatan dikarenakan kondisi 
pandemi yang sedang terjadi saat ini yang dituangkan dalam dokumen Kerjasama (MoU, MoA atau Perjanjian Kerjsama/PKS) antara PPPNS, Dinas Perikanan Kabupaten Situbondo dan PT SSA. Setelah dilaksanakan koordinasi awal, maka sosialisasi kegiatan dilakukan dengan mengundang perwakilan nelayan di wilayah barat, tengah dan timur Kabupaten Situbondo. Hal ini dimaksudkan agar pelaksanaan ini tetap maksimal dengan melihat ketersediaan ruang kegiatan, sarana prasarana dan tetap mematuhi protokol kesehatan Covid-19. Untuk mengatasi keterbatasan peserta dan waktu pelatihan, maka pelaksanaan kegiatan workshop online dilakukan dengan aplikasi meeting online (Zoom) serta terpusat di ruang aula Dinas Perikanan Kabupaten Situbondo, sehingga pelaksanaan ini tidak hanya terbatas pada peserta yang hadir (offline) saja namun bisa diikuti melalui aplikasi meeting online (Zoom).

\section{HASIL DAN PEMBAHASAN}

Hasil yang dicapai pada kegiatan workshop online pembuatan kapal kecil untuk nelayan diantaranya :

\section{Penyusunan planing kegiatan yang akan dilakukan kegiatan workshop} online bersama Industri dan Dinas Perikanan Kabupaten Situbondo

Kegiatan ini dilakukan dengan merencanakan dan menyusun kegiatan serta berkoordinasi dengan pihak industri dan Dinas Perikanan Kabupaten Situbondo. Planning kegiatan yang akan dilakukan dengan menentukan tema kegiatan, waktu pelaksanaan serta tindak lanjut dari hasil kegiatan yang diperoleh. Ouput dari kegiatan ini adalah dokumen kerjasama (MoU, MoA atau PKS) antara PPNS, Pihak Industri (PT. SSA) maupun dari Dinas Perikanan Kabupaten Situbondo dalam rangka pelaksanaan kegiatan yang dilakukan. 

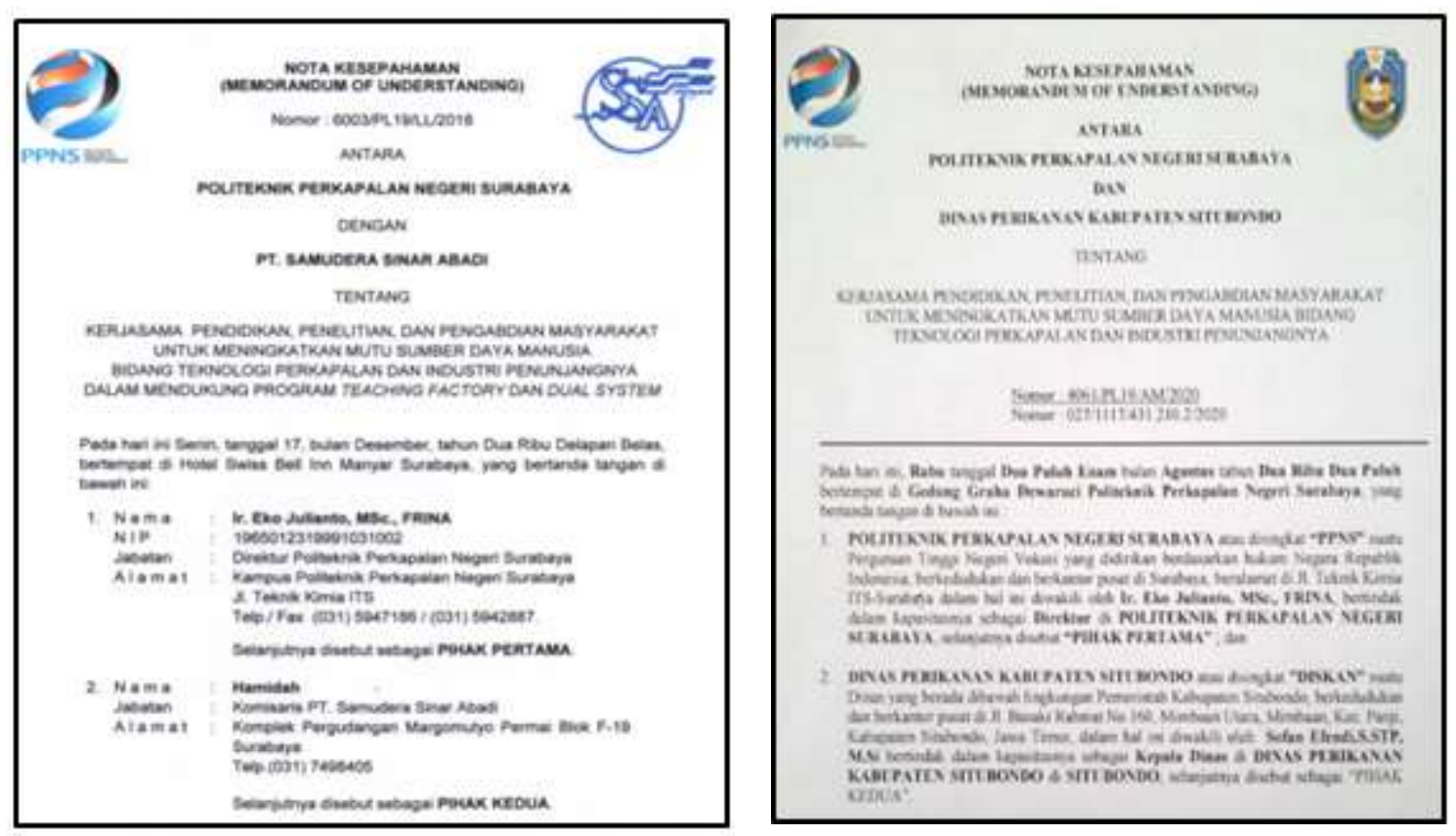

Gambar 4. Dokumen Kerjasama (MoU, MoA atau Perjanjian Kerja Sama)

Dokumen ini merupakan dokumen legalitas antara beberapa lembaga dalam melaksanakan kegiatan yang akan dilaksanakan, sehingga menjadi dasar atau acuan dalam pelaksanaan kegiatan yang akan dilaksanakan.

\section{Pembuatan video dan penyusunan handout kegiatan workshop online}

\section{pembuatan kapal kecil bagi nelayan}

Pada kegiatan selanjutnya yaitu pembuatan materi berupa video serta penyusunan handout bagi peserta nelayan. Pembuatan video dilakukan di kampus PPNS. Selain itu pembuatan handout merujuk pada materi Job Sheet bengkel non metal PPNS. Video dipilih sebagai media penunjang pelaksanaan kegiatan dikarenakan :

a. Para peserta masih terbatas dalam pemahaman tentang konsep dan cara pembuatan kapal kecil dari material FRP

b. Penyamaan konsep (penamaan) baik alat, bahan, bagian pada kapal serta proses pembuatan kapal yang berbeda digunakan untuk di setiap daerah dibandingkan standar yang ada

c. Proses pelaksanaan lebih menarik tidak hanya berupa materi saja namun para peserta diajak seolah-olah melakukan proses pembuatan kapal kecil terkait kondisi pandemi yang terjadi. 

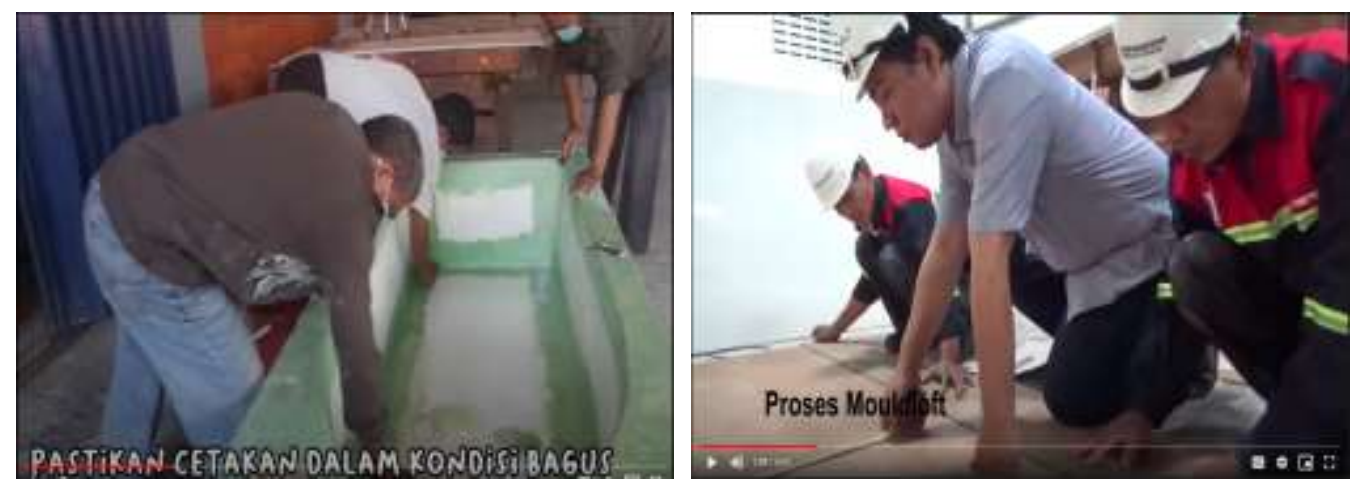

Gambar 5. Video tutorial pembuatan kapal kecil

Selain berupa video saat pelaksanaan kegiatan, kami mencoba untuk membuat handout terkait pembuatan kapal kecil yang berisi antara lain: pengertian kapal FRP, ukuran utama kapal, langkah pembuatan kapal beserta foto di setiap bagian, hingga proses finishing. Handout ini dibagikan kepada para peserta (nelayan, para pemilik kapal, instansi terkait) sebagai ringkasan pedoman singkat cara pembuatan kapal kecil, sehingga dengan adanya materi yang diberikan oleh para narasumber, video pembuatan kapal kecil serta pemberian handout diharapkan dapat meningkatkan pemahaman para peserta.
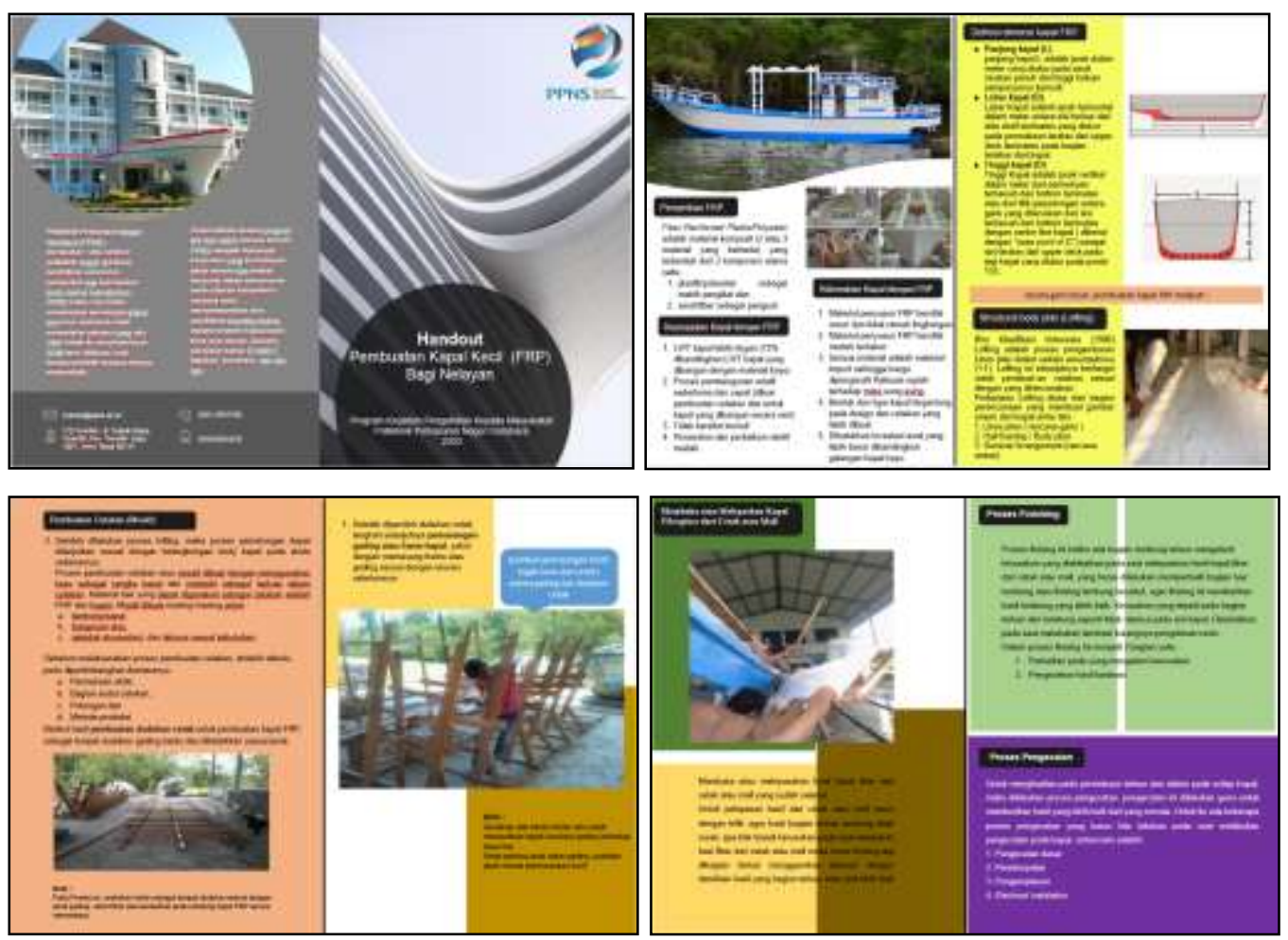

Gambar 6. Handout pembuatan kapal kecil (FRP) bagi nelayan 


\section{Persiapan sarana dan prasarana kegiatan workshop online sesuai SOP}

\section{Protokol Kesehatan Covid-19}

Persiapan sarana dan prasarana kegiatan dilakukan dengan koordinasi dengan pihak Dinas Perikanan Kabupaten Situbondo. Persiapan ini dilakukan dengan memperhatikan luasan tempat/aula, jumlah peserta kegiatan dan panitia serta sarana prasarana dalam menyikapi pandemi Covid-19.
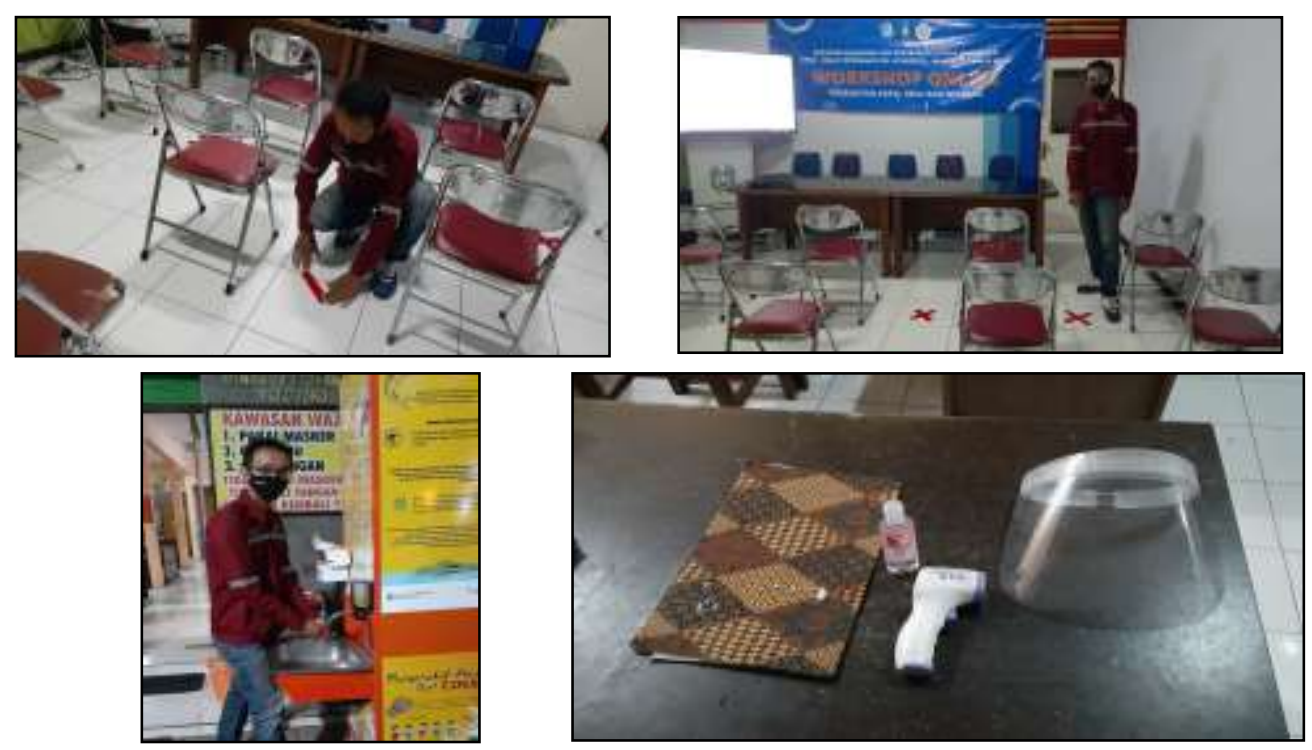

Gambar 7. Persiapan sarana dan prasarana kegiatan sesuai SOP Protokol Covid-19

\section{Pelaksanaan kegiatan workshop online pembuatan kapal kecil bagi nelayan}

Pelaksanaan kegiatan workshop online dilakukan dengan Zoom meeting serta terpusat di ruang aula Dinas Perikanan. Kegiatan ini juga mendapat support dari pihak Pemda yakni, dari Dinas Kominfo dan Persandian Kabupaten Situbondo yang membantu dalam sarana prasarana terkait dengan online meeting melalui media Zoom meeting.
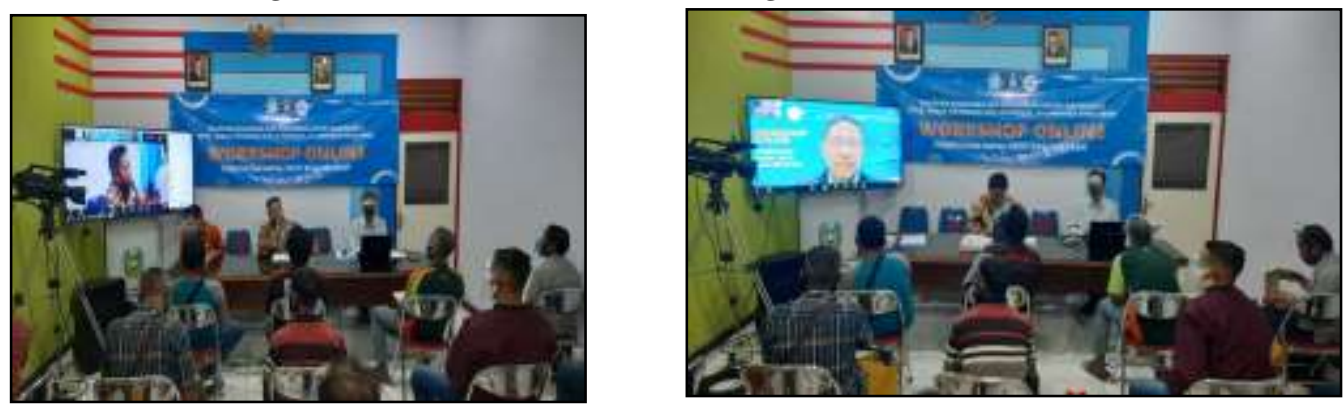

Gambar 8. Sambutan dari Kepala Dinas Perikanan Kabupaten Situbondo dan penyampaian materi kegiatan 
Pelaksanaan dimulai dengan presentasi dari tiap narasumber (Galangan PT. SSA dan dosen PPNS Surabaya), dilanjutkan dengan sesi tanya jawab baik pertanyaan secara langsung yang diajukan oleh peserta luring (nelayan) serta daring (peserta umum), diakhiri dengan pengisian kuesioner sebagai evaluasi dan tindak lanjut untuk kegiatan selanjutnya
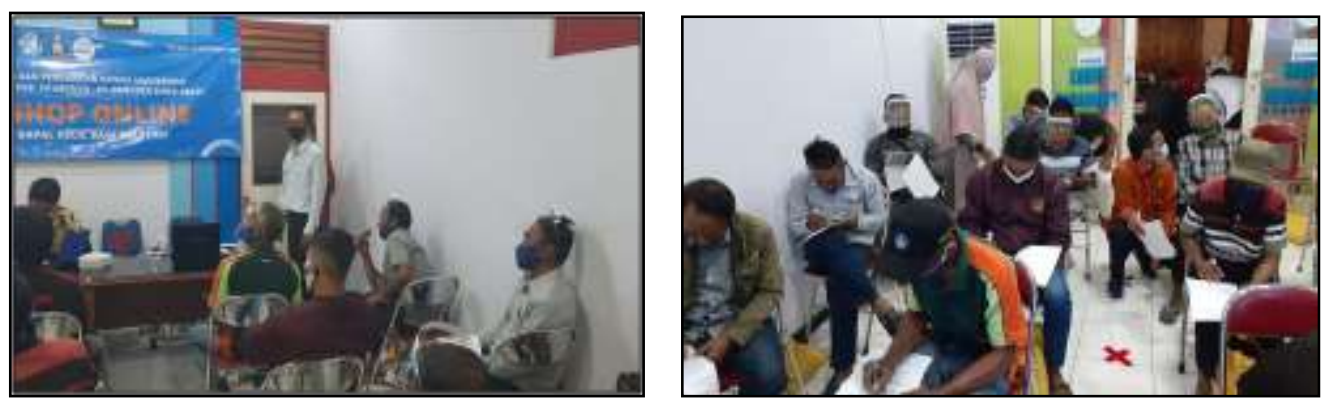

Gambar 9. Proses pengajuan pertanyaan dan pengisian kuesioner peserta kegiatan

\section{KESIMPULAN}

1. Kegiatan workshop online adalah salah satu solusi kegiatan pengabdian kepada masyarakat dalam kondisi yang serba terbatas yakni kondisi pandemi Covid19.

2. Program penerapan Link and Match Vokasi antara (Perguruan Tinggi, Industri, dan Pemerintah) yang sebelumnya kurang maksimal dapat dilakukan dengan memaksimalkan sarana prasarana (Infokom) tanpa mengabaikan kepentingan antar lembaga.

3. Dengan adanya workshop "Pembuatan Kapal Kecil bagi Nelayan" dapat memberikan informasi terbaru khususnya para nelayan di daerah pesisir Panarukan, Situbondo, tentang proses pembuatan kapal kecil yang berbahan material baru (fiberglass/FRP).

4. Memberikan kesempatan kepada masyarakat/nelayan untuk mendapatkan pengetahuan langsung cara pembuatan kapal dari pihak galangan kapal, praktisi dan pengajar dari pihak akademisi.

5. Antusias dalam pelaksanaan kegiatan sangat baik. Ini bisa dilihat dari hasil kuesioner umpan balik (feedback) yang dilakukan oleh peserta secara daring (73 orang) dan luring (15 orang) mendapatkan hasil dimana rata-rata nilai 
indikator kesesuaian workshop diatas $86 \%$, serta usulan kegiatan lanjutan dengan praktek langsung diatas angka $78 \%$.

\section{UCAPAN TERIMA KASIH}

1. Kepala Dinas Perikanan Kabupaten Situbondo beserta seluruh karyawan yang telah mendukung dan memberi fasilitas berupa sarana dan prasarana hingga para peserta kegiatan, sehingga kegiatan ini dapat berjalan dengan baik dan lancar

2. Kepala Dinas Kominfo dan Persandian Kabupaten Situbondo yang telah mendukung dalam penyediaan sarana kegiatan online, sehingga pelaksanaan berjalan dengan lancar

3. Komisaris PT. Samudera Sinar Abadi selaku narasumber dari industri, sehingga sharing materi dalam pelaksanaan kegiatan pembuatan kapal kecil untuk nelayan di Kabupaten Situbondo dapat maksimal dengan menampilkan kegiatan real di industri

4. Ketua Jurusan Teknik Bangunan Kapal-PPNS, sebagai narasumber dari pihak akademisi telah bersedia mengisi sharing materi terbarukan melalui teori dan pengalaman dalam pembuatan kapal kecil, sehingga pelaksanaan kegiatan pengabdian masyarakat antara (Pihak Pemerintah-Akademisi-Industri) berjalan dengan baik.

\section{DAFTAR PUSTAKA}

Coackley, N. (1991). Fishing Boat Construction: 2 Building a Fiberglass Fishingboat. Food and Agriculture Organiztion (FAO). Rome

McVearh, et.al. (2010). Training Manual on the construction of FRP beach landing boats. Food and Agriculture Organiztion (FAO). Rome

PPNS. (2019). Modul Job Sheet Praktek Non-Metal. 